THE INTERNATIONAL

REVIEW OF RESEARCH IN

OPEN AND DISTANCE LEARNING

\title{
Odyssey of the Mind: Social Networking in Cyberschool
}
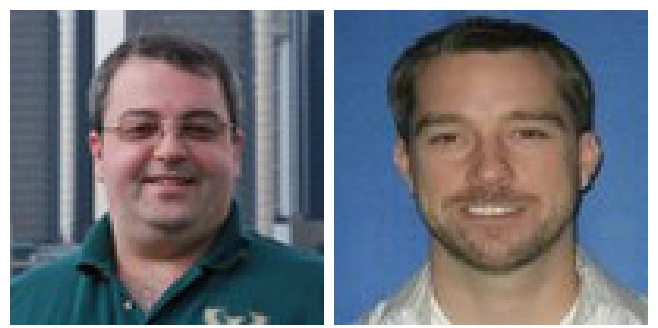

Michael K. Barbour

Wayne State University, USA

Cory Plough

Odyssey Charter High School, USA

\section{Abstract}

K-12 online learning and cyber charter schools have grown at a tremendous rate over the past decade. At the same time, these online programs have struggled to provide the social spaces where students can interact that K-12 schools are traditionally able to provide. Social networking presents a unique opportunity to provide these kinds of social interactions in an online environment. In this article, we trace the development and use of social networking at one cyber charter school to extend the space for online instruction and provide opportunities for social interaction that online schools are often unable to provide.

Keywords: K-12 online learning; virtual school; cyberschool; social networking

K-12 online learning in the United States, both supplemental and full-time, has it roots in the 1990s (Barbour, 2010; Clark, 2003; Darrow, 2010). Approximately a decade after K-12 online learning first began, Clark (2001) reported there were at least 14 states with existing or planned virtual schools and approximately 40,000 students enrolled. Watson, Murin, Vashaw, Gemin, and Rapp (2011) stated that there is now significant K-12 online learning activity in all 50 states, while Wicks (2010) estimated the overall number of K-12 students engaged in online courses to be approximately two million. Participation in cyber charter schools has also increased during this time. Huerta and González (2004) estimated that there were approximately 60 cyber charter schools in 15 states serving over 16,000 students. More recently, Watson et al. (2011) reported there were over 250,000 students learning online full-time in 30 states.

In their review of the literature, Barbour and Reeves (2009) described five challenges of $\mathrm{K}-12$ online learning. These included the high start-up costs associated with virtual schools, access issues surrounding the digital divide, approval or accreditation of virtual schools, 
student readiness issues, and retention issues. Not included in the list of challenges was the issue of transactional or perceived distance that may be experienced by the students due to a potential lack of social interaction and socialization. K-12 schools are traditionally social spaces often with time built into the school schedule for student interaction outside of class, student participation in extracurricular activities, and student involvement in formal activities such as school dances and other planned social events (Merrell, 2002; Tasmajian, 2002). All of these social opportunities are difficult to replicate in an online setting, presenting a unique challenge for K-12 online schools as they attempt to serve the needs of their students.

In this article, we discuss one online school's attempt to address the social aspect of their students' experience by using social networking. Specifically, we begin by briefly describing the theory of transactional distance and discussing the role of the school as an agent for the socialization of children. Next, we describe the methodology for this action research project, beginning with the online school in question, that is the Odyssey Charter High School (OCHS) in Nevada, USA. We then trace the development of social networking at OCHS. Using these experiences, we discuss some of the lessons learned by the staff at OCHS. Finally, we examine the use of this social network to provide the out-of-class interaction that online schools are often unable to provide, which should decrease the sense of transactional distance experienced by students.

\section{Theory of Transactional Distance}

One of the most widely accepted theories of distance education at present is the theory of transactional distance (Moore, 1972, 1973, 1983, 1993; Moore \& Kearsley, 1996). Like most other theories of distance education, this theory was based on adult learners in a distance environment. Based upon the work of Malcolm Knowles, one of the founders of the field of adult education, Moore conjectured that it was natural for an adult learner to exhibit autonomous behavior, which was why distance education programs should seek to have a low level of transactional distance (i.e., a high level of dialogue and a low level of structure) to maximize the opportunities for the autonomous adult learner.

Knowles (1970) stated that there were four assumptions about adult learners that were different from assumptions about child learners:

1) his self-concept moves from one of being a dependent personality toward one of being a self-directing human being; 2) he accumulates a growing reservoir of experience that becomes an increasing resource for learning; 3) his readiness to learn becomes oriented increasingly to the developmental tasks of his social roles; and 4) his time perspective changes from one of postponed application of knowledge to immediacy of application, and accordingly his orientation toward learning shifts from one of subject- 
centeredness to one of problem-centeredness. (p. 39)

Moore (1973) himself also speculated that even though the quality of autonomy, based upon Erikson's stages of development, emerges in infancy, that this ego quality may not be the same as autonomy of learning and that "it may well be that, as learners, people are struggling in an 'autonomy versus shame and doubt' crisis in grade school, high school, or university" (p. 667). Even Bright (1989), in his critique of adult learning theory, stated "it is not being suggested that there are no differences between adults and children. On the contrary, there are probably many..." (p. 55). All of these individuals agree that there are fundamental differences in the orientation that adults have to learning compared to the way in which children and adolescents learn.

Vygotsky (1962) observed that, unlike the education of adult learners, learning for a child was a social process that focused upon interaction within a zone of proximal development. The zone of proximal development "is the distance between the actual developmental level as determined by independent problem solving and the level of potential development as determined through problem solving under adult guidance or in collaboration with more capable peers" (Vygotsky, 1978, p. 86). Cavanaugh et al. (2004) suggested, "since adults have progressed through these stages of cognitive development, delivery of web based education at the adult level need not concentrate on methods that help the learner develop these cognitive skills" (p. 7). The methods designed to help the child learner develop cognitive skills are intended as guidance provided to these learners to ensure that they remain in the zone of proximal development.

Moore (1973) noted that typically in K-12 education teachers were expected to maintain control of the content and method of delivery within the classroom. These students "should not be compelled to assume a degree of autonomy they are not ready to handle, and so it is customary in child education for the preparatory and evaluation processes to rest entirely in the hands of the teacher" (p. 84). According to adult education experts, children are not ready to assume high degrees of autonomy, and thus child and adolescent learners require more structure in their educational settings, particularly in distance education settings (such as online schools) where the lack of proximity to the teacher decreases one of the main sources of guidance to the learners in their zone of proximal development. The addition of structure, along with the continued high level of dialogue, to support the child learner in a virtual school environment may serve to replace some of that guidance.

\section{Role of the School as an Agent for Socialization}

Durkin (1995) defined socialization as "the process whereby people acquire the rules of behavior and systems of beliefs and attitudes that equip a person to function effectively as a member of a particular society" (p. 614). Similarly, Giddens, Duneier, and Appelbaum (2005) defined socialization as "the process by which, through contact with other human beings, one becomes a self-aware, knowledgeable human being, skilled in the ways of a given culture and environment" (p. 7). Within the educational context, Irwin and Berge 
(2006) wrote that "socialization [was] about people being able to mingle and establish connections on one or more levels. They speak [with] one another; share ideas and information and confirm the connections made through an agreed upon means" (I 3). Essentially, it is how children learn the social norms that will be expected of them as adults in society.

In many instances, it is the $\mathrm{K}-12$ school environment that is the primary "agency responsible for socializing groups of young people in particular skills and values in our society" (Long, 2007, I 9). Tasmajian (2002) argued that schools serve this function because "school is the first agency that encourages children to develop loyalties and sentiments that go beyond the family and link them to a wider social order" (p. ๆ 9). Watson and Gemin (2008) further argued that it was "because a child or teenager spends so much time in school, the educational environment is clearly a key part of the student's socialization" (p. 4). While the use of K-12 online learning has grown substantially in the past two decades, there has been concern that a lack of face-to-face contact might hinder the process of socialization for these students. As Sivin-Kachala and Bialo (2009) have indicated, "there is a lack of research addressing the effects of online schooling on socialization and the development of social skills" (p. 5). In en effort to address this deficit, we provide the OCHS and its social networking site as a descriptive example of one way an online school has attempted to provide this socialization function.

\section{Methodology}

The purpose of this project was to examine the effectiveness of a closed social network as a way to increase socialization in a full-time online school and to decrease transactional distance. This project used a multiphase, action research methodology (Mills, 2011). Action research was an appropriate methodological approach for this study because it is "insider research, in the sense of practitioners researching their own professional action" (McNiff, Lomax, \& Whitehead, 1996, p. 14). The practitioners in question were teachers and administrators at OCHS in Clark County School District (CCSD) in the U.S. state of Nevada.

While this action research project occurred in three phases, systematic data was only collected during the second semester of the second phase. Phase 1 and the first semester of Phase 2 served as an orientation for the practitioners involved and included smaller numbers of students. The second semester of Phase 2, the implementation of the social network, was opened to all students and data was collected. The primary researcher used a look-think-act model (Stringer, 2004), which involves collecting relevant information and then using that information to undertake actions designed to improve upon that which is being studied. The data that were collected included interviews with the students, teachers, and administrators; observations of students, teachers, and administrators, using the social network; and usage statistics maintained within the social network system. Finally, Phase 3 included revisions to the use and polices of the social network based on the results of the study described here. Phase 3 is also the manner in which the social network is currently operating. 


\section{Setting: Odyssey Charter High School (OCHS)}

OCHS began as a sponsored online, public charter school of the Clark County School District (CCSD) in 1999 using a hybrid model. The majority of courses are taught online, but there is a face-to-face component in which students attend class one day a week for four hours. During those four face-to-face hours, students take a Core Values class that resembles a traditional, direct instruction course. For the remainder of the time on campus (known as homeroom), they meet with a series of mentor teachers who help them organize their coursework, check their progress, and address their academic needs. Students remain in one room and while at school usually only interact with the other 10-20 students in that room.

Online teachers work full-time on campus. Teachers are responsible for mentoring approximately 40 students along with their online teaching course loads. In most cases, teachers meet their online students by seeking them out during homerooms. However, there are instances where the teacher may never meet all of their online students. Because students only interact with about 20 other students and have limited physical interaction with their online teachers, a small group of teachers at the OCHS decided in 2006 to create a social network for the school. The following sections describe the social network at OCHS, which is called Odyssey of the Mind.

\section{Intervention: Odyssey of the Mind}

The evolution of the social networking site currently utilized by the OCHS (i.e., Odyssey of the Mind) began with frustrations two teachers had with the limited interaction, particularly social interaction, between themselves and their students (see boyd \& Ellison, 2007, for a general description and history of social network sites). Their efforts led to experimentation with various social networking sites and, eventually, the creation of a single NING (see http://www.ning.com/) network for students enrolled in the online high school.

\section{Phase 1: Early attempts at social networking.}

Due to the nature of teaching at an online school and the difficulty of teacher to student communication, a teacher at OCHS decided to begin using social networking during the 2006-2007 school year. The initial attempts began with one teacher using private or closed Facebook (see http://www.facebook.com) groups for each of his online courses and inviting students to join voluntarily. The purpose was to meet students where they were hanging out online (Lenhart \& Madden, 2007), and the teacher was pleased with some of the discussion that occurred in those groups. However, there were limitations to the Facebook groups. They didn't provide enough incentive for students to join or to participate. There were also structural constraints on the kind of networking that could be done within these groups (e.g., the teacher was limited to discussions and wall board comments within the group page, not wanting to utilize other aspects of Facebook due to his concerns over privacy). Finally, while the teacher was pleased with some of the discussion, there was not as much socialization as he had hoped. 
Ultimately, safety concerns were the main issue with the Facebook groups (see Dwyer, Hiltz, \& Passerini, 2007 for an overview of this issue). While the teacher was able to make these groups private, students still had profile pages in which they controlled the security settings. Like many teenagers and young adults (Stutzman, 2006), the OCHS students chose to make their profiles public, which opened the door for anyone to communicate with them. Thus, the teacher began looking for alternatives to Facebook and discovered the NING social networking system.

\section{Phase 2: The creation of Odyssey of the Mind.}

The NING platform provided the ability to create and administer one's own network. This addressed many of the problems that had been experienced with Facebook as students would be able to have all the functions of a social network (e.g., picture and music uploads, group formations, discussion forums, blogging, and profile sharing) while in a setting where the creator could choose to exclude anyone not associated with the courses. During the 2007-2008 school year, the teacher created Odyssey of the Mind as a social network in NING for students in his online courses. Initially there were approximately 60 students who joined during the first semester.

The teacher perceived that everything had gone very well, and no safety issues arose; yet there was still not a lot of activity. Like many participatory sites, social networks need participants to keep them active. Sixty students were not enough to keep participation at a consistent, sustained level. This teacher began to collaborate with the OCHS assistant principal, who had been piloting a similar NING network with his own course, to create a network that involved students from both of their courses. The networks of the assistant principal were combined with this teacher's, and students from the courses taught by five other teachers were invited. This expanded the Odyssey of the Mind NING network and it ran as a pilot program for the second semester of the 2007-2008 school year.

\section{Phase 3: Current Odyssey of the Mind.}

At the beginning of the 2008-2009 school year the Odyssey of the Mind NING network was opened to all OCHS students and staff. All 750 students, along with 27 teachers and administrators, were sent an invitation to join the network. At the end of the first quarter, there were 321 students and approximately a dozen teachers involved. The same teacher and assistant principal who began experimenting with social networks at OCHS administered the new NING network. To assist in this monitoring process, a program has been written to search for language violations, and six of the most active students have been recruited to help monitor music, group discussions, and blogging for violations and safety and behavioral issues. Finally, there is an RSS feed of latest activity sent to OCHS aggregators, which helps keep track of student activity. 


\section{Results and Discussion}

The results presented below were based solely on the data collected during the second semester of Phase 2. These results are organized into two main themes: administrative lessons from the pilot project and the nature of interaction observed in the social network.

\section{Lessons from the Pilot Project}

The OCHS pilot program, which occurred during the spring of 2008 for one semester, intended for each teacher to be responsible for leading projects with their online students and monitoring their students' activities. However, there were some limitations in this area. The pilot had approximately 200 students in the network, many of whom had two or more teachers who were participating. While teachers were successful in completing projects and discussions with their classes in the network, the monitoring for safety and behavioral issues fell on the two administrators. OCHS learned in the pilot program that there needed to be a more systematic method for monitoring student behavior, and that if teachers were to be involved there had to be very specific and well-defined roles for each educator.

\section{Curricular and cocurricular activities in a social network.}

All seven teaching staff involved in the pilot program led curricular-related projects or discussions in the social network with their students. Students felt that the social network provided a more relaxed environment to work with teachers and somewhere that they were already spending significant time for social reasons. This was consistent with Mazer, Murphy, and Simonds (2007), who found that students appreciated their teachers' efforts to use a social networking site. One teacher had students collaborating on their final quarter project within their NING group by reviewing peers' ideas and offering suggestions on sample work. The social network also allowed students from different classes to more easily be involved in joint or cross-course projects, such as a global "Save Darfur" student campaign.

In addition to teacher-driven activities, students also used the social network for academic purposes. While the teachers created groups for each of their courses, the students chose to use these groups for course planning and participation; for example, in one of the physical education classes the teacher provided students a chance to decide on which sports they would play in the class. The students also created and operated their own tutorial groups. This allowed them to answer each other's questions, point out specific resources, and help each other navigate lessons. In his study of high school students learning online, Barbour (2007) found that students would seek help from their student colleagues before seeking help from their teachers or from curricular materials (e.g., textbooks and online course materials). Barbour described these as learning communities that develop in the online environment because there are "like-minded groups of people [who gather] together in the spirit of shared goals" (Conrad, 2002, p. 4), in this instance the goal of understanding or completing course material.

The social network also provided students a place to discuss their problems regarding online teachers or courses. As a school that primarily caters to a population of at-risk stu- 
dents (i.e., Clark and Berge [2005] described at-risk students as remedial and alternative, while Rapp, Eckes, and Plurker (2006) described them as students who might otherwise drop out of traditional schools), concerns or issues students have with their teachers and courses (e.g., organization, lessons, assignments, and grading) have the potential to create roadblocks to success. The social network gave students a forum to discuss those concerns with other students. The sharing of problems allowed students to determine if they were experiencing similar issues, and when there was a collective concern (e.g., a student posted a concern about unfair grading in one course to a discussion forum and found that others had the same concern) the students were able to report it to OCHS administration through the social network. In another discussion, students gave suggestions about what the school could do to improve. There was a lengthy set of comments on this topic during the pilot program, which was then shared with the high school administration and the school improvement committee. Cross (1998) indicated that a learning community was intended to foster "active learning over passive learning, cooperation over competition, and community over isolation" (p. 5). As the students began to create an online learning community in the social network, they began to take a more active, cooperative role in their overall schooling experience.

Students responded well to the freedom of open discussion and idea sharing. They even created groups that became active on campus. For example, during the pilot program there was a student group formed to raise money for the World Wildlife Fund (WWF). The initial five students organized some meetings at school, developed a product, sold that product, and wrote their first check to the WWF in little more than a month after the group was first created. This group has continued to be active since the pilot program has become a schoolwide social network.

One of the main limitations of the OCHS learning management system was that there was no easy way for students to meet each other or work together with students outside of their individual courses. As evidenced by these examples, the social network provided both the platform and the opportunity for students to collaborate beyond the confines of their own class. The learning management system also did not provide a resource for students to seek real-time assistance from teachers when they needed help with their online coursework. Barbour (2007) found that the two most important factors high school students learning online took into account when making decisions about where to turn for assistance were the availability of the source (i.e., being able to reach that person quickly) and the deadline (i.e., when the project was due). The social network provided a mechanism that allowed students to see whenever teachers were logged onto the network.

\section{Safety and behavioral concerns and teaching opportunities.}

The most important aspect of running a social network for any school is student safety. The reason OCHS decided to use a NING social network for their pilot program, and later their main school network, was because it gave the administrators the ability to operate a walled garden. This meant that no one could join the network that was not invited to join. Since no one outside of the school could communicate with the students inside the walled garden, 
parents were more comfortable with the idea of allowing their children to join. In order to further accommodate parent safety concerns, all students who are under the age of 18 must have a parent sign a permission form before they can join.

Another issue was the publishing of offensive and inappropriate material. In MySpace or Facebook, the school was not able to control what students saw or heard while using those networks (Ofcom, 2008). However, using a private NING network allowed OCHS to monitor uploaded pictures, music playlists, and published videos. It also allowed them to monitor student discussions and comments on profile pages. The main rule for the network has been, "Keep it clean, this is an extension of the classroom." However, OCHS also has parents and students sign off on an acceptable use policy (AUP), which forbids publishing any explicit material or the use of offensive language in the network.

OCHS understood students were going to make mistakes when using a social network at school. Given the nature of the network, which allowed students to be in charge of most of the content creation, the network creators knew this could lead to some inappropriate behavior. Students were used to operating in MySpace and/or Facebook with little concern about oversight or behavioral consequences. A goal of OCHS was to create a space where young people could learn how to act professionally online. The teachers and administrators use student mistakes, such as explicit playlists or offensive language in the forums, as teachable moments. As well, the NING network provides an opportunity for teachers to help students become aware of the potential consequences of publishing personal or sensitive information online.

\section{Interaction in an Online School through Social Networking}

Various kinds of interaction have occurred in the social network. Some have been planned interactions by the teachers and administrators of OCHS, but most have been student generated. The staff-led and student-led interactions can be grouped in two ways: pedagogical and social.

\section{Pedagogical interaction.}

As a hybrid school, OCHS requires students to be on campus for four hours one day a week. Beyond those four hours, there is no opportunity for face-to-face time between students and teachers or students and other students. During the four hours each week when the students are on campus, most of them work the entire time and there is often little interaction. The social network offered an opportunity for students to make connections to peers in an otherwise isolated learning environment. This was an important feature as Barbour (2009) found that getting to know their online classmates was one of the main challenges students identified in their online learning experience. The social network also gave them the opportunity to connect with others who were sharing similar experiences.

One of the goals of the network was to offer a place for students to discuss and participate in their own learning. For example, the Principles of Leadership course had students design their social network home page for an early semester 'About Me' project and turn 
the assignment in through their NING group. In another case, students created a course area for the Algebra 1B class where they offered assistance to other students in that course. Karabenick and Knapp (1991) found that students seeking help was negatively related to the students' sense of the risk to their perceived social standing for seeking help. As the social network is a place where students can interact and seek the academic assistance they need without having to physically face their colleagues, this may have served to increase the frequency of this kind of activity (along with the number of students who participated).

Another goal of the social network was to provide students with a more profound sense of connection to the school, which could lead to greater motivation and academic achievement. Communication at an online school is typically very formal with teachers sending e-mails and making telephone calls to students regarding schoolwork. There was often little opportunity to get to know students on a more personal level in the same way teachers are able to in a traditional school. The social network provided a casual environment that helped teachers to build stronger personal relationships with their online students (Hewitt \& Forte, 2006) and to create opportunities to increase student motivation (Cayanus, 2004). In addition, students had an easier method to reach teachers and other students at all hours of the day if they needed help on an assignment or just someone to speak with. Golder, Wilkinson, and Huberman (2007) found that school-based users of social networks typically interact with each other outside of traditional school hours. The immediacy of these communications could also serve to increase student motivation (Christophel, 1990).

As many of the OCHS students were considered to be at-risk students, the staff at OCHS used the social network to create an atmosphere where students could gain confidence because they were given an opportunity to make friends, locate a source of help when they needed content-based assistance, and engage in open and safe discussions, which may have provided some students with the needed belief that they could succeed in school. Berge and Clark (2005) identified the potential to provide opportunities for at-risk students to be successful as one of their five benefits of K-12 online learning. The social network has also given students a resource for self-expression and identity development, which might not otherwise exist in an online education environment.

\section{Social interaction.}

In a traditional school environment, students often have the opportunity to become involved in a variety of extracurricular activities. As a hybrid school with a significant online component, OCHS did not have clubs or other activities available to students. However, with the introduction of the social network, students started forming interest groups. At the end of the first semester, there were 119 groups in the social network, only a dozen of which had been created by teachers. Students have created all of the other groups on topics such as theater, web design, mixed martial arts, comic books, anime, teen documentary, film and acting, and writing.

Along with the groups, there have been numerous discussions about nonacademic topics that are important to the development of youth adults (Fraser, 1992). Students have talked 
about politics and the presidential election. There were blog and discussion posts about career goals. There was a robotics get-together planned, and several other nonacademic projects have also developed. Students created public service announcements about societal concerns such as school violence and dropout rates. Finally, there was an acting group that was attempting to produce a comedy sketch to perform for the entire school.

Using the social network, students recently organized prom and talent show committees. OCHS has never had a prom or a talent show so creating these from scratch was quite an endeavor. The prom committee was raising money, planning the theme, researching the facility, and organizing all of the intricate details at the time of writing. They had even created a new NING social network branching off from the Odyssey of the Mind network in order to conduct all of the necessary planning. The talent show committee was accepting proposals with hope of the event occurring in spring 2009. Essentially, the social network has been the public space that has allowed the students a sphere for their social development (boyd, 2007), similar to the kind of public space they would have experienced in the traditional school environment.

In addition to student-centered cocurricular and extracurricular groups, there were several groups that focused on students offering emotional support to others. "Unite the Outcasts," "Gay/Straight Alliance," and "Special Ed Kids" were all groups specifically started so students could talk about teen social problems. Each one had a distinct theme, yet they were all examples of students reaching out to fellow students to speak about topics they would normally have hidden from others throughout their school careers. In their research on peer networks that develop in adolescence, Steinberg, Brown, and Dornbusch (1996) identified three groups: best friends, clique, and crowd. They defined the crowd as being composed of individuals who shared things in common but were not necessarily friends. While all of the students enrolled at OCHS shared some common contexts (i.e., they were all students enrolled at OCHS), these groups provided a space for them to come together around specific interests, attitudes, and/or desired activities.

There were also over 15 active bloggers in the social network community. These were all students who were voicing their ideas about numerous topics that concerned them. Some of their posts focused on their online courses, others on music and the arts, but many of them related specifically to the emotional and psychological difficulties of adolescence. What made this surprising to the staff of the OCHS was the fact that these teenagers felt comfortable enough to reveal themselves to an online viewership of nearly half of the school population. A very small portion faced ridicule for their posts (something that often provided an opportunity for a teachable moment), but most students have reacted very positively and great conversations ensued. Modeling has been a useful tool during these teachable moments. Bandura (1997) described modeling as an effective teaching tool because it has the potential to provide information about how tasks should be performed.

One of the most active forms of interaction has come from the student-led discussions about teen problems. As of the writing of this article there were 64 active discussions in the forums, with approximately one quarter of them focused on social issues, teen problems, 
or ethical dilemmas. In his stages of human development, Erikson $(1958,1968,1982)$ described adolescence as a stage where humans must achieve their identity, as opposed to identity diffusion. Many of the conflicts during this stage of achieving identity focus upon resolving one's beliefs about major personal and social issues. For example, in the social network there were discussions about depression, boyfriends/girlfriend problems, parent issues, interracial relationships, religion, and life after death. All of these topics are included in the kinds of issues that adolescents must come to terms with to develop their own identity. In this instance, Schunk's (1991) finding that peer modeling was more effective than teacher modeling is relevant. Thus, allowing students to discuss issues that are related to the formation of their own identity and allowing them to model for each other how to conduct a serious, empathetic, and thoughtful discussion can facilitate their personal development.

It has been difficult for the staff at OCHS to imagine many of these student-led groups and discussions occurring in a public manner at a traditional high school. Many students came to OCHS because of social problems or problems they were experiencing at their large high schools. The social network has provided a place to form groups and discussions with likeminded individuals, many of whom often felt that they had to hide their voices. Enochsson (2007) speculated that social networks might provide an accessible medium to give shy students a voice. The fact that there was still a measure of anonymity because there was a high likelihood that these students would not meet each other in person may have also contributed to this phenomenon, allowing students to be more revealing about themselves without fear of facing the people they are talking to at a later date.

Recently, OCHS added rules for using their forums. Since they gave students the opportunity to create the majority of the network content, students had the ability to have very frank discussions about difficult material. There was no way a teacher could moderate every discussion, so there were periodic violations of the OCHS AUP. In some instances, students got overly passionate about a topic, which led to insults of other students. In an attempt to create a more respectful environment and mediate concerns over possible cyber-bullying, OCHS instituted a new set of guidelines for public discussions that prohibited insults and offensive or derogatory commentary. As participation in peer networks has been found to influence academic motivation in adolescents (Dweck \& Goetz, 1978; Ryan, 2000), and research has also indicated that students who are more academically motivated tend to have larger peer networks (Kindermann, McCollam, \& Gibson, 1996), there is a strong desire by the staff at OCHS to keep students participating and engaged in the social network.

\section{Conclusions and Implications}

One main goal of the social network was to provide a safe place for students to collaborate with peers they would likely never meet and teachers they rarely had the opportunity to see face-to-face. Learning in an online environment can be a socially isolating experience; as such, the network creators also hoped to provide a platform for students to discuss their personal and schooling experiences with their peers. The final goal was to help motivate 
students by making their educational and social experiences more dynamic. It was hoped that theses three goals would serve to decrease the transactional distance that students experienced.

The pilot program demonstrated some of the beliefs the creators had about socialization at an online school. For example, they believed that although many students had come to OCHS because of social hardships, they still had a desire to interact with their peers. It also reinforced the idea that students could benefit by having other students to discuss coursework with or, at the very least, by making contacts so they could get help when needed. As many students never met their classmates during the face-to-face school sessions, the social network provided a medium to allow these meetings to occur. Educators at OCHS also witnessed students engaging in ways they had not envisioned or even experienced before in the OCHS environment. This engagement included social interaction, sharing personal histories, and connecting with classmates about important course curriculum.

The main concern during both the pilot program and the eventual school-wide NING network was student safety. Choosing a walled garden through NING, rather than an open platform (such as Facebook), allowed the network creators to take responsibility for the content of the network as well as those the students were able to interact with. Network administration determined who was allowed to access the social network by using a system of security checks, which included such things as signing up using a school email, having parents sign a permission form, and matching the names of the network applicants to a master student list. Network administrators also employed students and staff to help monitor the appropriateness of music, language, and pictures uploaded into the network. Although there was always fear of students harassing each other, the administrators have only seen a small amount of this kind of behavior. And there was no concern about stranger sfrom outside of the OCHS school system gaining access to the student population.

For administrators considering the creation of a social network for their online schools, there are four issues to consider. First, at OCHS maintaining children's safety and security was at the forefront of every decision. Letters, which detailed the reasons behind starting the network and highlighted the positive aspects of social networking at an online school, were sent to parents/guardians of those who wished to join. In addition, parents/guardians signed consent letters to give their children permission to join the network and to agree to an acceptable use policy. Second, OCHS made the social network a volunteer activity. This meant that students did not have to join the network. It also meant that those who did join were more interested in maintaining a positive environment and helped monitor the hundreds of pages on the site. Third, OCHS used a simple software program that searched the private Ning network for keywords and flagged pages that violated the acceptable use policy. Finally, the school asked for teacher volunteers to log in daily and monitor different groups, conversations, and student interactions in order to maintain a safe and positive environment. Based on our experiences, we would recommend that online school administrators consider these issues when exploring the implementation of their own social networks. 


\section{References}

Barbour, M. K. (2007). What are they doing and how are they doing it? Rural student experiences in virtual schooling (Unpublished doctoral dissertation). University of Georgia, Athens, GA.

Barbour, M. K., (2009). Useful and challenging characteristics of virtual schooling: Secondary student experiences. Quarterly Review of Distance Education, 4(9), 357-372.

Barbour, M. K. (2010). Researching K-12 online learning: What do we know and what should we examine? Distance Education, 7(2), 7-12.

Barbour, M. K., \& Reeves, T. C. (2009). The reality of virtual schools: A review of the literature. Computers and Education, 52(2), 402-416.

Bandura, A. (1997). Self-efficacy: The exercise of control. New York: Freeman.

Berge, Z. L., \& Clark, T. (2005). Virtual schools: Planning for success. New York, NY: Teachers College Press.

boyd, d., \& Ellison, N. (2007). Social network sites: Definition, history, and scholarship. Journal of Computer-Mediated Communication, 13(1). Retrieved from http:// jcmc.indiana.edu/vol13/issue1/boyd.ellison.html

boyd, d. (2007). Social network sites: Public, private, or what? Knowledge Tree, 13. Retrieved from http://kt.flexiblelearning.net.au/tkt2007/edition-13/social-networksites-public-private-or-what/

Bright, B. P. (1989). Epistemological vandalism: Psychology in the study of adult education. In B. P. Bright (Ed.), Theory and practice in the study of adult education: The epistemological debate (pp. 34-64). London, U.K.: Routledge.

Cavanaugh, C., Gillan, K. J., Kromrey, J., Hess, M., \& Blomeyer, R. (2004). The effects of distance education on $\mathrm{K}-12$ student outcomes: A meta-analysis. Naperville, IL: Learning Point Associates. Retrieved from http://www.eric.ed.gov/ERICWebPortal/detail?accno=ED489533

Cayanus, J. L. (2004). Effective instructional practice: Using teacher self-disclosure as an instructional tool. Communication Teacher, 18, 6-9.

Christophel, D. M. (1990). The relationships among teacher immediacy behaviors, student motivation, and learning. Communication Education, 39, 323-340.

Clark, T. (2001). Virtual schools: Trends and issues - A study of virtual schools in the United States. San Francisco, CA: Western Regional Educational Laboratories. Retrieved from http://www.wested.org/online_pubs/virtualschools.pdf 
Clark, T. (2003). Virtual and distance education in American schools. In M. G. Moore \& W. G. Anderson (Ed.), Handbook of distance education (pp. 673-699). Mahwah, NJ: Lawrence Erlbaum Associates.

Clark, T., \& Berge, Z. L. (2005). Perspectives on virtual schools. In Z. L. Berge \& T. Clark (Eds.), Virtual schools: Planning for success (pp. 9-19). New York, NY: Teachers College Press.

Conrad, D. (2002). Deep in the hearts of learners: Insights into the nature of online community. Journal of Distance Education, 17(1), 1-19.

Cross, K. P. (1998). Why learning communities? Why now? About Campus, 3(3), 4-11.

Darrow, R. W. (2010). A comparative study between online charter high schools and traditional high schools in California (Unpublished doctoral dissertation). California State University, Fresno, CA.

Durkin, K. (1995). Socialization. In A. Manstead \& M Hewstone (Eds.), The Blackwell encyclopedia of social psychology. Cambridge, MA: Basil Blackwell.

Dweck, C. S. \& Goetz, T. (1978). Attributions and learning helplessness. In J. Harvey, W. Ickes, \& R. Kidd (Eds.), New direction in attribution research (pp. 157-179). Hillsdale, NJ: Erlbaum.

Dwyer, C., Hiltz, S. R., \& Passerini, K. (2007). Trust and privacy concern within social networking sites: A comparison of Facebook and MySpace. Proceedings of the Thirteenth Americas Conference on Information Systems, Keystone, CO. Retrieved from http://csis.pace.edu/ dwyer/research/DwyerAMCIS2007.pdf

Enochsson, A. B. (2007). Tweens on the Internet: Communication in virtual guest books. Seminar.net, 3(2). Retrieved from http://www.seminar.net/images/stories/vol3issue2/enochsson-tweens_on_the_internet.pdf

Erikson, E. H. (1950). Childhood and society. New York: W. W. Norton \& Co.

Erikson, E. H. (1968). Identity and the life cycle. New York: W. W. Norton \& Co.

Erikson, E. H. (1982). The lifecycle completed. New York: W. W. Norton \& Co.

Fraser, N. (1992). Rethinking the public sphere: A contribution to the critique of actually existing democracy. In C. Calhoun (Ed.), Habermas and the public sphere (pp. 109-142). Cambridge, MA: MIT Press.

Giddens, A., Duneier, M., \& Appelbaum, R. (2005). Introduction to sociology ( $5^{\text {th }}$ edition). New York: W.W. Norton \& Company, Inc.

Golder, S., Wilkinson, D., \& Huberman, B. (2007). Rhythms of social interaction: Messag- 
ing within a massive online network. In C. Steinfield, B. Pentland, M. Ackerman, \& N. Contractor (Eds.), Proceedings of Third International Conference on Communities and Technologies (pp. 41-66). London: Springer. Retrieved from http:// www.hpl.hp.com/research/idl/papers/facebook/index.html

Hewitt, A., \& Forte, A. (2006, November). Crossing boundaries: Identity management and student/faculty relationships on the Facebook. A poster presentation at the annual Computer Supported Cooperative Work conference, Banff, AB. Retrieved from http://www.cc.gatech.edu/ aforte/HewittForteCSCWPoster2006.pdf

Huerta, L. A., \& González, M. F. (2004). Cyber and home school charter schools: How states are defining new forms of public schooling. Tempe, AZ: Education Policy Research Unit, Arizona State University. Retrieved from http://epsl.asu.edu/ epru/articles/EPRU-0401-49-OWI.htm

Irwin C., \& Berge, Z. (2006). Socialization in the online classroom. E-Journal of Instructional Science and Technology, 9(1). Retrieved from http://www.ascilite.org.au/ ajet/e-jist/docs/vol9_no1/papers/full_papers/irwin_berge.htm

Karabenick, S. A., \& Knapp, J. R. (1991). Relationship of academic help seeking to the use of learning strategies and other instrument achievement behavior in college students. Journal of Educational Psychology, 88, 260-271.

Kindermann, T.A., McCollam, T. L., \& Gibson, E. Jr. (1996). Peer networks and students' classroom engagement during childhood and adolescences. In J. Juvonen \& K. R. Wentzel (Eds.), Social motivation: Understanding children's school adjustment (pp. 279-312). Cambridge, England: Cambridge University Press.

Knowles, M. S. (1970). The modern practice of adult education: Andragogy vs. pedagogy. New York, NY: Association Press.

Lenhart, A., \& Madden, M. (2007). Social networking websites and teens: An overview. Washington, DC: Pew Internet \& American Life Project. Retrieved from http:// www.pewinternet.org/pdfs/PIP_SNS_Data_Memo_Jan_2007.pdf

Long, R. (2007). Socialization. Bern, Switzerland: Lumrix.net GmbH. Retrieved from http://www.lumrix.net/medical/sociology/socialization.html

McNiff, J., Lomax, P., \& Whitehead, J. (1996). You and your action research project. London: Routledge.

Mazer, J. P., Murphy, R. E., \& Simonds, C. J. (2007). I'll see you on "Facebook": The effects of computer-mediated teacher self-disclosure on student motivation, affective learning, and classroom climate. Communication Education, 56 (1), 1-17.

Merrell, K. W. (2002). Assessment of children's social skills: Recent developments, best 
practices and new directions. Exceptionality, 9, 3-18.

Mills, G. E. (2011). Action research: A guide for the teacher researcher $\left(4^{\text {th }}\right.$ ed.). Boston, MA: Pearson Education, Inc..

Moore, M. G. (1972). Learner autonomy: The second dimension of independent learning. Convergence, Fall, 76-88.

Moore, M. G. (1973). Toward a theory of independent learning and teaching. Journal of Higher Education, 44(12), 661-679.

Moore, M. G. (1983). The individual adult learner. In M. Tight (Ed.), Education for adults: Volume 1 - Adult learning and education (pp. 153-168). London, U.K.: Croom Helm Ltd.

Moore, M. G. (1993). Theory of transactional distance. In D. Keegan (Ed.), Theoretical principles of distance education (pp. 22-38). London: Routledge.

Moore, M. G., \& Kearsley, G. (1996). The theoretical basis for distance education. In Distance education: A systems view (pp. 197-212). Belmont, CA: Wadsworth.

Ofcom. (2007). Social networking: A quantitative and qualitative research report into attitudes, behaviors and use. London: Author. Retrieved from http://www.ofcom. org.uk/advice/media_literacy/medlitpub/medlitpubrss/socialnetworking/report. pdf

Picciano, A. G., \& Seaman, J. (2007). K-12 online learning: A survey of US school district administrators. Needham, MA: Alfred P. Sloan Foundation. Retrieved from http://www.sloan-c.org/publications/survey/K-12_06.asp

Rapp, K. E., Eckes, S. E., \& Plurker, J. A. (2006). Cyber charter schools in Indiana: Policy implications of the current statutory language. Education Policy Brief, 4(3). Retrieved from http://ceep.indiana.edu/projects/PDF/PB_V4N3_Winter_2006_ CyberCharter.pdf

Ryan, A. (2000). Peer groups as a context for the socialization of adolescent's motivation, engagement, and achievement in school. Educational Psychologist, 35, 101-111.

Schunk, D. H. (1991). Learning theories: An educational perspective. New York: Macmillan.

Sivin-Kachala, J., \& Bialo, E. (2009). IESD Comprehensive technical report: Evaluation of the social skills of full-time, online public school students. New York: Interactive Educational Systems Design, Inc. Retrieved from http://www.k12.com/educators/ research__results/reports__white_papers/socialization-study/

Steinberg, L., Brown, B. B., \& Dornbusch, S. M. (1996). Beyond the classroom: Why school 
reform has failed and what parents need to do. New York: Simon \& Schuster.

Stringer, E. (2004). Action research in education. Upper Saddle River, NJ: Pearson Education, Inc..

Stutzman, F. (2006). An evaluation of identity-sharing behavior in social network communities. Journal of the International Digital Media and Arts Association, 3(1), 10-18. Retrieved from http://www.ibiblio.org/fred/pubs/stutzman_pub4.pdf

Tasmajian, D. (2002). Socialization skills acquired by elementary school children. Undergraduate Research Journal for the Human Sciences, 1. Retrieved from http:// www.kon.org/urc/tasmajian.html

Tucker, B. (2007). Laboratories of reform: Virtual high schools and innovation in public education. Washington, DC: Education Sector. Retrieved from http://www.educationsector.org/research/research_show.htm?doc_id=502307

Vygotsky, L. S. (1962). Thought and language (E. Hanfmann \& G. Vakar, Trans.). Cambridge, MA: The M.I.T. Press.

Vygotsky, L. S. (1978). Mind in society: The development of higher psychologist processes. Cambridge, MA: Harvard University Press.

Watson, J. F., \& Gemin, B. (2008). Promising practices in online learning: Socialization in online programs. Vienna, VA: North American Council for Online Learning. Retrieved from http://www.inacol.org/research/promisingpractices/NACOL_PP_ Socialization.pdf

Watson, J., Murin, A., Vashaw, L., Gemin, B., \& Rapp, C. (2011). Keeping pace with K-12 online learning: An annual review of policy and practice. Evergreen, CO: Evergreen Education Group. Retrieved from http://kpk12.com/cms/wp-content/uploads/KeepingPace2011.pdf

Wicks, M. (2010). A national primer on K-12 online learning, Version 2. Vienna, VA: International Association for K-12 Online Learning. Retrieved from http://www.inacol.org/research/bookstore/detail.php?id=22

\section{Athabasca University $\mathbf{I}$}

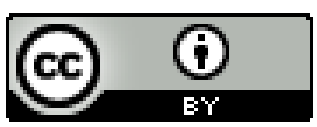

